\title{
Study of basic environmental performance indicators of a coal mining enterprise
}

\author{
Vladimir Mikhailov ${ }^{1 *}$, Tatyana Galanina ${ }^{1}$, Svetlana Bugrova $^{1}$, Yana Mikhailova ${ }^{1}$, and \\ Evdokiya Kulpina ${ }^{1}$ \\ ${ }^{1}$ T.F. Gorbachev Kuzbass State Technical University, Department of Production Management, \\ 650000 Kemerovo, 28 Vesennyaya st., the Russian Federation
}

\begin{abstract}
Current processes of environmental law enforcement require the use of innovative approaches to the problem of environmental management. In this regard, an adequate choice of the environmental performance indicators of an enterprise and the technique for their analysis, aimed at developing efficient, environmentally friendly management decisions, is of great importance. The technique for calculating the environmental and eco-economic performance indicators of a coal mining enterprise, including using the weighted average hazard class of pollutants or production and consumption waste is discussed in the article. Various options for the application of this approach, which is of practical importance for reducing the labor intensity of management decisionmaking by industrial enterprises, are considered.
\end{abstract}

\section{Introduction}

One of the main functions of environmental management at an enterprise is the analysis of cost effectiveness of environmental activities. The analysis of environmental performance indicators of enterprises, especially in coal mining [1-3], is the most important component of the environmental management system at the macro and micro levels $[4,5]$.

The purpose of the analysis of environmental performance indicators of enterprises is to form an information basis for making decisions in the field of environmental management, focused on improving the environmental protection activities of an enterprise and increasing the efficiency of the use of natural resources.

To assess the balance between production activities and environmental protection at an enterprise, the most informative indicators (capable of providing a complete analysis in terms of temporal relationships and relationships within the "environment-production" system) should be selected, since the quality of the source information largely depends on the quality of environmental management models.

*Corresponding author: mvg.eohp@ @uzuzstu.ru 


\section{Results and Discussion}

Improving environmental protection at the present stage of economic development consists in the efficient management of eco-economic systems of various levels [6-11], which requires the use of eco-economic indicators providing maximum information content with minimum labor intensity of their calculation.

At the same time, it is important to keep an accurate record of the mass of pollutants, which can be expressed not only by the sum of the actual values, but also by the reduced mass, which makes it possible to determine the toxicity of each ingredient to obtain a mono-pollutant. Many eco-economic indicators, such as economic damage from negative impact on the environment and its derivatives $[12,13]$ are calculated on the basis of a mono-pollutant.

When solving most of eco-economic problems, the problem of taking into account the hazard class of pollutants arises, which is especially important for large industrial enterprises with highly diversified negative impact.

The calculation of the weighted average hazard class of a pollutant [12, 13], determined by the actual or reduced weight of a pollutant, is proposed in this paper. The reduced mass of a pollutant allows determining the toxicity of individual ingredients through the indicator of relative hazard as the reciprocal of the maximum allowable concentration - formula (1).

$$
H C_{W A}=\frac{\sum_{i=1}^{n} M_{i} \cdot H C_{i}}{M_{\text {total }}},
$$

where $H C_{W A}$ - weighted average hazard class of pollutants; $i$ - type of pollutant; $n$ - total amount of pollutants; $H C_{i}-$ hazard class of the $i$-th pollutant; $M_{\text {total }}$ - total reduced weight of pollutants, conv. t.

$$
M_{\text {total }}=\sum_{i=1}^{n} M_{i}
$$

where $\mathrm{M}_{\mathrm{i}}$ - reduced mass of the $i$-th pollutant, conv. $\mathrm{t}$, which is calculated by the formula (3):

$$
\mathrm{M}_{\mathrm{i}}=\mathrm{m}_{\mathrm{i}} \cdot \mathrm{A}_{\mathrm{i}},
$$

where $\mathrm{m}_{\mathrm{i}}-$ actual mass of the $i$-th pollutant, $\mathrm{t} ; \mathrm{A}_{\mathrm{i}}$ - indicator of the relative hazard of the $i$-th pollutant, conv. $\mathrm{t} / \mathrm{t}$, which is calculated by the formula (4):

$$
A_{i}=\frac{1}{R I_{i}}
$$

where $R I_{i}$ - regulatory indicator of the $i$-th pollutant, $\mathrm{mg} / \mathrm{m}^{3}$. The daily average maximum allowable concentration of the $i$-th pollutant $\left(\mathrm{MAC}_{\mathrm{Di}}\right)$, the one-time maximum

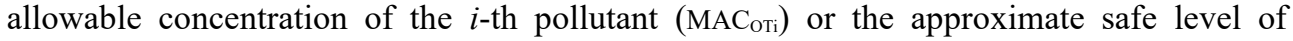
exposure to the $i$-th pollutant (ASLE ) can be used as a regulatory indicators.

Table 1 shows the results of calculating the reduced mass of pollution by the JSC Chernigovets enterprise on the basis of official data. Codes of pollutants are shown in brackets.

Table 1 shows that the enterprise emits pollutants of III and IV hazard classes into the air. Nitrogen dioxide (III hazard class), inorganic dust with $\mathrm{SiO}_{2}$ content up to $20 \%$ (IV hazard class), carbon monoxide (IV hazard class) and inorganic dust with $\mathrm{SiO}_{2}$ content from 20 to $70 \%$ (IV hazard class) have the largest actual mass. Based on the data from the Table, and in accordance with formulas (1) - (4), the calculation of the weighted average 
hazard class of pollutants emitted by the JSC Chernigovets enterprise into the air, which is equal to III.

$$
H C_{W A}=\frac{17833.2 \cdot 3+10600.7 \cdot 4}{28433.9}=3.37 \approx 3
$$

Table 1. The results of calculating the reduced mass of the main air pollutants by the JSC Chernigovets enterprise

\begin{tabular}{|c|c|c|c|c|c|c|}
\hline \multirow[t]{2}{*}{ Pollutant } & \multirow[t]{2}{*}{ Code } & \multirow[t]{2}{*}{$\mathbf{m}_{\mathrm{i}}, \mathbf{t} / \mathbf{y}$} & \multicolumn{2}{|c|}{ Regulatory indicator, $\mathrm{mg} / \mathrm{m}^{3}$} & \multirow{2}{*}{$\begin{array}{c}A_{i}, \\
\text { conv. } \\
t / t\end{array}$} & \multirow{2}{*}{$\begin{array}{c}M_{i}, \\
\text { conv. } \\
t / t\end{array}$} \\
\hline & & & Indicator & Value & & \\
\hline Iron oxide & 0123 & 1.020 & $\mathrm{MAC}_{\mathrm{Di}}$ & 0.04 & 25 & 25.5 \\
\hline Nitrogen dioxide & 0301 & 2851.996 & MACoTi & 0.2 & 5 & 14260 \\
\hline Nitrogen oxide & 0304 & 464.428 & МАСоті & 0.4 & 2.5 & 1161.1 \\
\hline Carbon (soot) & 0328 & 225.186 & MACOTi & 0.15 & 6.67 & 1502 \\
\hline Sulfur dioxide & 0330 & 321.196 & MACоTi & 0.5 & 2 & 642.4 \\
\hline $\begin{array}{l}\text { A mixture of } \mathrm{C}_{1}- \\
\mathrm{C}_{5} \text { saturated } \\
\text { hydrocarbons }\end{array}$ & 0415 & 56.83 & $\mathrm{ASLE}_{\mathrm{i}}$ & 50 & 0.02 & 1.1 \\
\hline $\begin{array}{l}\text { A mixture of } \mathrm{C}_{6}- \\
\mathrm{C}_{10} \text { saturated } \\
\text { hydrocarbons }\end{array}$ & 0416 & 32.680 & ASLE $_{i}$ & 30 & 0.03 & 1 \\
\hline Kerosene & 2732 & 389.236 & $\mathrm{ASLE}_{\mathrm{i}}$ & 1.2 & 0.83 & 240.1 \\
\hline III hazard class total & & & & & & 17833.2 \\
\hline Carbon monoxide & 0337 & 1724.286 & MACoTi & 5 & 0.2 & 344.9 \\
\hline $\begin{array}{l}\text { Methylbenzene } \\
\text { (Toluene) }\end{array}$ & 0621 & 1.064 & МАСоті & 0.6 & 1.67 & 1.8 \\
\hline $\begin{array}{l}\text { A mixture of } \mathrm{C}_{12}- \\
\mathrm{C}_{19} \text { saturated } \\
\text { hydrocarbons }\end{array}$ & 2754 & 10.836 & MACoTi & 1 & 1 & 10.8 \\
\hline $\begin{array}{l}\text { Inorganic dust: } 70- \\
20 \% \text { of } \mathrm{SiO}_{2}\end{array}$ & 2908 & 1444.583 & MACоTi & 0.3 & 3.33 & 4810.5 \\
\hline $\begin{array}{l}\text { Inorganic dust: up } \\
\text { to } 20 \% \text { of } \mathrm{SiO}_{2}\end{array}$ & 2909 & 1739.373 & MACoTi & 0.5 & 2 & 3478.7 \\
\hline Wood dust & 2936 & 3.405 & ASLE $_{i}$ & 0.5 & 2 & 6.8 \\
\hline Coal ash & 3714 & 70.128 & ASLE $_{i}$ & 0.3 & 3.33 & 233.5 \\
\hline Coal dust & 3749 & 171.365 & ASLE $_{\mathrm{i}}$ & 0.1 & 10 & 1713.7 \\
\hline IV hazard class total & & & & & & 10600.7 \\
\hline TOTAL & & & & & & 28433.9 \\
\hline
\end{tabular}

Economic damage from negative impact on the air $\left(\mathrm{ED}_{\mathrm{a}}\right)$ is calculated by the formula (5):

$$
E D_{a}=\gamma_{a} \cdot C_{i n d} \cdot C_{E S a} \cdot M_{a},
$$

where $\gamma_{\text {a Equation.3 }}$ - specific economic damage from air pollution by one conventional ton of harmful substances, 47,5 RUB/conv. t; $C_{E S a}$ Equation.3 - the coefficient of the environmental situation for the air (for the Kemerovo region, as for an industrialized 


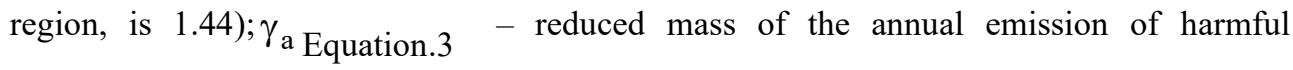
substances into the air, conv. $\mathrm{t} / \mathrm{y} \cdot \mathrm{M}_{\mathrm{a}}$ Equation.3 is calculated by the formula 6 :

$$
\mathrm{M}_{\mathrm{a}}=\sum_{\mathrm{i}_{\mathrm{a}}=1}^{\mathrm{n}_{\mathrm{a}}} \mathrm{m}_{\mathrm{a}_{\mathrm{i}}} \cdot \mathrm{A}_{\mathrm{a}_{\mathrm{i}}},
$$

where $\mathrm{m}_{\mathrm{a}_{\mathrm{i}}}$ - actual mass of the $i$-th air pollutant, $\mathrm{t} ; \mathrm{i}_{\mathrm{a}}$ - type of air pollutant; $n_{a}$ - total amount of air pollutants; $\mathrm{A}_{\mathrm{a}_{\mathrm{i}}}$ - indicator of the relative hazard of the $i$-th pollutant (conv. $\mathrm{t} / \mathrm{t}$ ), which is determined by the formula 4 .

For this calculation, the daily average maximum allowable concentration, and in its absence, the one-time maximum allowable concentration or an approximate safe level of exposure, is used as a priority regulatory indicators.

$$
E D_{a}=47.5 \cdot 1.08 \cdot 1.44 \cdot 28433.9=2100.47 \text { thousandRUB }
$$

Table 2 presents data on production and consumption waste of the JSC Chernigovets enterprise, indicating their codes in accordance with the Federal Waste Classifier Catalogue (WFCC).

The Table 2 shows that waste of the V hazard class (mainly overburden) amounts for more than $99 \%$ of the total mass of the generated waste. If we consider other types of waste, then the maximum mass is this type of waste of the IV hazard class as sludge from cesspools (3375 tons). The method of waste management is of great importance for increasing the efficiency of environmental protection activities. In this case, $93.7 \%$ of the total amount of waste transferred for recycling to external parties is waste of IV hazard class. Overburden (low hazard waste of V class) is disposed by the enterprise independently in compliance with environmental requirements.

Below is the calculation of the weighted average waste hazard class.

$$
H C_{W A}=\frac{12.31 \cdot 2+88.332 \cdot 3+3502.599 \cdot 4+175001378.868 \cdot 5}{175004982.109}=4.99 \approx 5
$$

Table 2. Generation of production and consumption waste at the JSC Chernigovets enterprise

\begin{tabular}{|l|l|c|c|c|}
\hline Waste type and hazard class & WFCC code & \multirow{2}{*}{$\mathbf{m}_{\mathbf{i}}, \mathbf{t} / \mathbf{y}$} & \multicolumn{2}{|c|}{ Waste use, t/y } \\
\cline { 3 - 5 } & & & $\begin{array}{c}\text { Transfer to } \\
\text { external } \\
\text { parties }\end{array}$ & Disposal, t/y \\
\hline $\begin{array}{l}\text { Used undamaged lead-acid } \\
\text { batteries with electrolyte }\end{array}$ & 92011001532 & 12.31 & 12.31 & - \\
\hline II hazard class total & & 12.31 & 12.31 & - \\
\hline Waste mineral motor oils & 40611001313 & 49.316 & 49.316 & - \\
\hline Waste mineral gear oils & 40615001313 & 5.559 & 5.559 & - \\
\hline $\begin{array}{l}\text { Halogen-free waste mineral } \\
\text { hydraulic oils }\end{array}$ & 40612001313 & 27.738 & 27.738 & - \\
\hline $\begin{array}{l}\text { Used oil filters for motor } \\
\text { vehicles }\end{array}$ & 92130201523 & 3.774 & 3.774 & - \\
\hline $\begin{array}{l}\text { Used fuel filters for motor } \\
\text { vehicles }\end{array}$ & 92130301523 & 1.945 & 1.945 & - \\
\hline III hazard class total & 73310001724 & 67.315 & & 67.315 \\
\hline $\begin{array}{l}\text { Unsorted waste of office and } \\
\text { domestic premises (excluding } \\
\text { bulky waste) }\end{array}$ & & & & \\
\hline
\end{tabular}




\begin{tabular}{|l|c|c|c|c|}
\hline Waste tires & 92111001504 & 56.648 & 56.648 & - \\
\hline $\begin{array}{l}\text { Used air filters for motor } \\
\text { vehicles }\end{array}$ & 92130101524 & 3.636 & 3.636 & - \\
\hline Waste from cesspools & 73210001304 & 3375 & 3375 & - \\
\hline IV hazard class total & & 3502.599 & 3435.284 & 67.315 \\
\hline $\begin{array}{l}\text { Mechanical sludge from open } \\
\text { pit water treatment in coal } \\
\text { mining }\end{array}$ & 21128111395 & 128.868 & 128.868 & - \\
\hline Low hazard overburden mix & 20019099395 & 175001250 & - & 127570250 \\
\hline V hazard class total & & 175001378.868 & 128.868 & 127570250 \\
\hline TOTAL & & 175004982.109 & 3664.794 & 127570317.315 \\
\hline
\end{tabular}

Accounting for waste transferred to external parties organizations is of great importance in the analysis of eco-economic indicators. Weighted average hazard class of waste transferred to third parties:

$$
H C_{w a}=\frac{12.31 \cdot 2+88.332 \cdot 3+3435.284 \cdot 4+128.868 \cdot 5}{3664.794}=4
$$

The economic damage from the disposal of production and consumption waste, differentiated by hazard classes (ED WASTE$)$, can be calculated by the formula 7 :

$$
E D_{\text {WASTE }}=5 \sum_{j=1}^{n_{\text {WASTEX }}} R_{P_{-} E L j} \cdot C_{\text {ind }} \cdot C_{E S n} \cdot m_{\text {wastej }},
$$

where 5 - five-fold multiplier; $R_{P_{-} E L j}$ - the rate of payment within the established limits for the disposal of production and consumption waste of the $j$-th hazard class, RUB/t; $n_{\text {WASTE }}$ - number of waste hazard classes (differentiated from 1 to 5 ); $\mathrm{K}_{\ni C_{\Pi}}$ - the coefficient of the environmental situation for the soil (differentiated by region and for the Kemerovo region is 1.2$) ; m_{\text {wastej }}$ - actual mass of waste of the $j$-th hazard class, $\mathrm{t}$.

Table 3 shows the results of calculating the economic damage from the negative impact on the soil of production and consumption waste of the JSC Chernigovets enterprise

Table 3. The results of calculating the economic damage from the negative impact on the

\begin{tabular}{|c|c|c|c|c|}
\hline \multirow[t]{2}{*}{ Waste hazard class } & \multirow[t]{2}{*}{$\mathrm{M}_{\text {wastej, }} \mathrm{t} / \mathrm{y}$} & \multirow{2}{*}{$\begin{array}{l}\text { RPELj, } \\
\text { RUB/t }\end{array}$} & \multicolumn{2}{|c|}{ Economic damage } \\
\hline & & & $\begin{array}{l}\text { thousand } \\
\text { RUB }\end{array}$ & $\%$ \\
\hline II & 12.31 & 1990.2 & 158.76 & 0.01 \\
\hline III & 88.332 & 1327 & 759.56 & 0.06 \\
\hline IV & 3502.599 & 663.2 & 15052.55 & 1.19 \\
\hline $\mathrm{V}$ & 175001378.868 & 1.1 & 1247409.83 & 98.74 \\
\hline Total & & & 1263380.70 & 100.00 \\
\hline
\end{tabular}
soil of production and consumption waste of the JSC Chernigovets enterprise

The table 3 shows that during the operation of a coal mining enterprise, the maximum share in the total value of the economic damage caused is occupied by waste of $\mathrm{V}$ hazard class $-98.74 \%$, which is about 1.25 billion rubles.

The main idea of using this regulatory method modification is that the entire mass of pollution is considered in excess of limits, for which a five-fold multiplier is applied. 


\section{Conclusion}

Analysis of the environmental performance indicators of a coal mining enterprise using the technique for calculating the weighted average hazard class of pollutants based on the actual or reduced mass or production and consumption waste is of practical importance when conducting the following studies:

- calculation of economic damage from negative impact on the environment and other eco-economic indicators;

- determination of the hazard class of an enterprise, including for the purpose of exemption from pollution charges;

- calculating the level of penalties for violation of environmental legislation and excessive negative impact;

- identification of environmental "bottlenecks" of an enterprise to plan the priority environmental protection measures;

- substantiation of the effectiveness of the use of one-time and current environmental costs;

- solving other eco-economic problems.

\section{References}

1. P. Kosinskiy, V. Merkuriev and A. Medvedev, E3S Web of Conf., 13403009 (2019)

2. P. Kosinskiy, A. Kharitonov, E. Wolfson and R. Takhtaeva, E3S Web of Conf., 174 04009 (2020)

3. Yu. A. Manakov, A. N. Kupriyanov and A. I. Kopytov, Ugol, 9, 89 (2018)

4. V. M. Tumin, A. G. Koryakov and E. P. Nikiforova, World Appied Sciences Journal 25(6), 945 (2013)

5. V. M. Tumin and A. G. Koryakov Middle East Journal of Scientific Research 17(9), 1350 (2013)

6. T. Tyuleneva, E3S Web of Conf., 2104009 (2017)

7. T. Tyuleneva, E3S Web of Conf., 17404019 (2020)

8. V. M. Zolotukhin, V. A. Gogolin, M. Yu. Yazevich, M. I. Baumgarten and A. V. Dyagileva, IOP Conf. Series: Earth and Env. Sci., 50, 012027 (2017)

9. V. Zolotukhin, N. Zolotukhina, M. Yazevich, A. Rodionov and M. Kozyreva, E3S Web of Conf., 2104008 (2017)

10. I. Kolechkina, I. Verchagina, E. Eltsova and M. Petrova, E3S Web of Conf., 134, 02004 (2019)

11. A. Islamgaleyev, C. Karibdzhanov and M. Petrova, Journal of Security and Sustainability Issues, 10(1), 165 (2020)

12. V. Mikhailov, V. Karasev and G. Mikhailov, E3S Web of Conf., 41, 02015 (2018)

13. T. V. Kiseleva, V. G. Mikhailov and G. S. Mikhailov, IOP Conf. Series: Earth and Env. Sci., 84, 012044 (2017)

14. Y. V. Ryumina, Economy of Region Issues, 12(4), 1113 (2016)

15. T. Y. Anopchenko, O. I. Gorbaneva, E. I. Lazareva, A. D. Murzin and G. A. Ougolnitsky, Advances in systems science and applications, 18(4), 136 (2018) 